\title{
Association of Diabetes and Outcomes in Patients with COVID-19: A Propensity Score Matched Analyses from a French Retrospective Cohort
}

\author{
Willy Sutter \\ PARCC
}

Baptiste Duceau

PARCC

Aurélie Carlier

Hopital Bichat - Claude-Bernard

Antonin Trimaille

Hopitaux universitaires de Strasbourg

Thibaut Pommier

Centre Hospitalier Universitaire de Dijon

Oriane Weizman

Centre Hospitalier Universitaire de Nancy

Joffrey Cellier

Hopital Europeen Georges Pompidou

Laura Geneste

Centre Hospitalier Universitaire Amiens-Picardie

Vassili Panagides

Assistance Publique Hopitaux de Marseille

Wassima Marsou

Centre Hospitalier Regional Universitaire de Lille

Antoine Deney

Centre Hospitalier Universitaire de Toulouse

Sabir Attou

Centre Hospitalier Universitaire de Caen

Thomas Delmotte

Centre Hospitalier Universitaire de Reims

Sophie Ribeyrolles

Institut Mutualiste Montsouris

Pascale Chemaly

institut cardiovasculaire paris sud

Clément Karsenty

Centre Hospitalier Universitaire de Toulouse

Gauthier Giordano

Centre Hospitalier Universitaire de Nancy

Alexandre Gautier

Institut cardiovasculaire Paris Sud

Corentin Chaumont

Centre Hospitalier Universitaire de Rouen

Pierre Guilleminot

Centre Hospitalier Universitaire de Dijon

Audrey Sagnard

Centre Hospitalier Universitaire de Dijon

Julie Pastier

Centre Hospitalier Universitaire de Dijon 
maxime Vignac

PARCC

delphine Mika

Université de Paris-Saclay

Charles Fauvel

CHIC Elbeuf

\section{Théo Pezel}

Hopital Lariboisiere Service de Cardiologie

\section{Ariel Cohen}

Hopital Saint-Antoine

Guillaume Bonnet

PARCC

Ronan Roussel

Hopital Bichat - Claude-Bernard

Louis POTIER ( $\square$ louis.potier@gmail.com )

Diabetology department Bichat Hospital, APHP https://orcid.org/0000-0001-6268-7360

\section{Original investigation}

Keywords: covid-19, mortality, propensity score

Posted Date: August 5th, 2020

DOI: https://doi.org/10.21203/rs.3.rs-51775/v1

License: (c) (i) This work is licensed under a Creative Commons Attribution 4.0 International License. Read Full License

Version of Record: A version of this preprint was published at Diabetes \& Metabolism on July 1st, 2021. See the published version at https://doi.org/10.1016/j.diabet.2020.101222. 


\section{Abstract}

Background: To compare the clinical outcomes between patients with and without diabetes admitted to hospital with COVID-19.

Methods: Retrospective multicentre cohort study from 24 academic tertiary medical centres in France including 2851 patients (675 with diabetes) hospitalised for COVID-19 between February 26 and April 20, 2020. A propensity score matching method (1:1 matching including patient characteristics, medical history, vital signs, and laboratory results) was used to compare patients with and without diabetes ( $\mathrm{n}=603$ in each group). The primary outcome was admission to intensive care unit (ICU) or in-hospital death.

Results: Patients with diabetes were older (71 \pm 13 vs. $65 \pm 18$ years; $p<0.001)$, were less often female ( $38 \%$ vs. $44 \%$; $p<0.001)$ and more likely to have comorbidities: hypertension (79\% vs $42 \%$; $p<0.001)$, coronary heart disease (23\% vs $9 \%$; $p<0.001)$, stroke (13\% vs $8 \%$; $p<0.001)$, heart failure (17\% vs $9 \%$; $p<0.001)$, chronic kidney disease (26\% vs $10 \% ; p<0.001)$, and chronic obstructive pulmonary disease $(7 \%$ vs $5 \%$; $p<0.05)$. The primary outcome occurred in 584 (36.4\%) patients with diabetes compared to $246(26.8 \%)$ in those without diabetes (p<0.001). After propensity score matching, the risk of primary outcome was similar in patients with and without diabetes (hazard ratio [HR] 1.16, $95 \% \mathrm{Cl} 0.95-$ $1.41, p=0.14)$ and was $1.29(95 \% \mathrm{Cl} 0.97-1.69)$ for in-hospital mortality, $1.26(95 \% \mathrm{Cl} 0.93-1.72)$ for mortality without transfer in ICU, and $1.14(95 \% \mathrm{Cl} 0.88-1.47)$ for transfer to ICU.

Conclusions: In this retrospective cohort of patients hospitalised for COVID-19, diabetes was not significantly associated with a higher risk of COVID-19 severe outcomes after propensity score matching.

Trial registration NCT04344327

\section{Background}

Since December 2019, coronavirus disease 2019 (COVID-19), a disease caused by the severe acute respiratory syndrome coronavirus 2 (SARS-CoV-2) has rapidly spread worldwide and has been declared as a pandemic by the World Health Organization. COVID-19 pandemic resulted in more than 400000 deaths across 200 countries. From the first Chinese publications, epidemiologic features have quickly identified diabetes as one the leading comorbidities associated with COVID-19 worse prognosis (1). Studies published so far provided consistent results with a two to three -fold higher prevalence of diabetes in patients in intensive care units compared with less severe cases, and a dramatic increase in mortality in patients with diabetes (1-4). Other comorbidities frequently associated with diabetes such as obesity, hypertension, chronic kidney disease or cardiovascular disease, have also been shown to be associated with higher risk of severe outcomes in COVID-19 (58). Whether diabetes is associated with worse COVID-19 outcomes independently of diabetes related comorbidities remains unclear. So far, there are only few published studies which directly compared patients with and without diabetes to address this issue (9-11). Moreover, despite multiple adjustments, comparison between patients with and without diabetes might remain biased by the important difference in terms of clinical characteristics, medical history but also clinical and biological presentation at admission. The aim of the present study is therefore to investigate the potential association between diabetes and clinical outcomes in patients hospitalized for COVID-19 by using a propensity score matched (PSM) approach accounting for a wide range of comorbidities.

\section{Methods}

\section{Study settings and population}

The Critical COVID-19 France (CCF) study is a retrospective, observational, multicentre study initiated by the French Society of Cardiology, including all consecutive adult patients admitted to hospital with a diagnosis of SARS-Cov-2 infection between February 26 and April 20 , 2020, in 24 centres (NCT04344327). The overall protocol has been in part describes in a previous report (12). Briefly, according to World Health Organization criteria, SARS-Cov-2 infection was defined as a positive result on real-time reverse transcriptase-polymerase chain reaction of nasal and pharyngeal swabs or lower respiratory tract aspirates, or as typical imaging characteristics on chest computed tomography when laboratory testing results were inconclusive. Given that transfer in intensive care unit (ICU) was one of the primary outcomes (see corresponding section below) patients directly admitted to ICU were excluded. The CCF study was declared to and authorized by the French data protection committee (Commission Nationale Informatique et Liberté, CNIL, authorization $\left.n^{\circ} 2207326 v 0\right)$, and was conducted in accordance with the ethical standards laid down in the 1964 Declaration of Helsinki and its later amendments.

\section{Data collection}

All data were collected by local investigators in an electronic case-report form via the REDCap software (Research Electronic Data Capture, Vanderbilt University) hosted by a secured server from the French Institute of Health and Medical Research at the INSERM Paris Cardiovascular Research Centre. General characteristics of patients included demographic characteristics, coexisting medical conditions, and 
chronic medications. Detailed data including clinical parameters, blood test results, and chest computed tomography characteristics (when performed) were recorded at admission. The degree of lung injuries on computed tomography was categorized as low (<25\% involvement), moderate ( $25 \%$ to $50 \%$ involvement), and severe (>50\% involvement). Only computed tomography scans performed during the first 24 hours were considered. Data on pharmacological therapies, mode of respiratory support, complications or associated diagnoses, and vital status were also gathered during the hospital stay. All therapies given during hospital stay (including pharmacological agents to treat SARS-Cov-2) were left to the discretion of the referring medical team.

Diabetes was defined as self-reported medical history of diabetes, prior medical records indicative of diabetes, or ongoing therapy with glucose-lowering medications.

\section{Outcomes}

The primary outcome was a composite of transfer in ICU or in-hospital death. Secondary outcomes were each component of the primary outcome, death in ICU and death without transfer to ICU. The date of the final follow-up for patients who remained hospitalized was April 21, 2020.

\section{Statistical analysis}

This report was prepared in compliance with the STROBE checklist for observational studies (13). Continuous data are reported as mean $( \pm S D)$ for normally distributed data and as median $\left(25^{\text {th }}\right.$ and $75^{\text {th }}$ percentile) for non-normally distributed data. Categorical data are reported as counts and percentages. Comparisons used the chi-squared test or Fisher's exact test for categorical variables and Student's $t$ test or the Mann-Whitney-Wilcoxon test, as appropriate, for continuous variables. Kaplan-Meier survival curves between patients with and without diabetes at hospital admission were plotted and compared by the log-rank test.

Since most of patients' characteristics, either covariates prior to admission or those related to medical presentation at admission, were dramatically different between patients with and without diabetes, we used a propensity-score-matched approach to better account for these differences. We used a 1:1 matching based on characteristics using a "nearest neighbor matching" algorithm and a caliper at 0.1 (14). Characteristics used for matching included: age, sex, body mass index (BMI), "prior to admission" characteristics (history of hypertension, dyslipidemia, cardiovascular disease, heart failure and chronic obstructive pulmonary disease, smoking status, renin angiotensin system (RAS) blockers use) and "at admission" characteristics (decision to withdraw of life-sustaining therapy, oxygen saturation, creatinine, aspartate aminotransferase, leucocytes count, C - reactive protein). We matched 603 participants (89.5\% and $27.8 \%$ of patients with and without diabetes before matching, respectively). After propensity score matching, all absolute standardized differences were $<10 \%$, indicating robust matching (14). Cox models were fitted for endpoints with diabetes as covariate in the matched cohort.

As sensitivity analysis, we also built two other propensity scores: (1) the first included, in addition to age, sex and BMI, all personal characteristics and comorbidities included in the main propensity score (history of hypertension, dyslipidemia, cardiovascular disease, heart failure and chronic obstructive pulmonary disease, smoking status, RAS blockers use); (2) the second included, in addition to age, sex and $\mathrm{BMI}$, all admission vitals and laboratory findings (decision to withdraw of life sustaining therapies, oxygen saturation, creatinine, aspartate aminotransferase, leucocytes count, $\mathrm{C}$ - reactive protein).

A two-tailed $\mathrm{P}<0.05$ was considered statistically significant. All data were analyzed using $\mathrm{R}$ software, version 3.6 .3 (R Project for Statistical Computing).

\section{Results}

\section{Patient characteristics}

Overall, 2,878 patients hospitalised for COVID-19 in 24 French centres were included between February 26 and April 20,2020 (list of participating centres in Supplemental table S1). Among them, 27 were excluded from analysis for missing data for outcomes or diabetes status (Figure 1). Clinical and biological characteristics of the 2,851 patients included for analysis overall and according to the diabetes status are presented in Table 1. The mean ( \pm SD) age was $67 \pm 17$ years and $1203(42.2 \%)$ were female. The prevalence of comorbidities at admission was: hypertension (50.7\%), diabetes (23.7\%), cardiovascular diseases (12.6\%), chronic heart failure (10.9\%) and chronic obstructive pulmonary disease (5.6\%). Regarding laboratory findings, levels of C - reactive protein were elevated whereas most of other laboratory findings at admission were in the normal range. Abnormalities on chest computed tomography were classified as severe in 427 (19\%) patients. The median time from symptom onset to admission was 7.0 [3.0;10.0] days and duration of hospital stay was 8.0 [5.0;12.0] days (Table 2). Antibiotic therapy was the most prescribed drug during hospitalization (74.4\%). Overall, anticoagulation therapy was prescribed during hospitalization in $88.2 \%$ of patients including prophylaxis-dose (63.2\%) and therapeutic-dose (18.5\%). 
Risk factors associated with outcomes in the overall population are reported in Supplemental Table S2. Briefly patients who experienced outcomes, compared with those who did not, had more often diabetes and diabetes related comorbidities such as hypertension, diabetes, dyslipidemia, chronic kidney disease, history of cardiovascular disease and heart failure.

\section{Comparison according to diabetes status in the unmatched cohort}

Compared to patients without diabetes, those with diabetes were older (mean age $71 \pm 13$ years vs. $65 \pm 18$ years), were less often female ( $38 \%$ vs. $44 \%$ ) and more likely to have medical history of hypertension ( $79 \%$ vs $42 \%)$, coronary heart disease ( $23 \%$ vs $9 \%)$, stroke ( $13 \%$ vs $8 \%$ ), chronic heart failure (17\% vs $9 \%$ ), chronic kidney disease (26\% vs $10 \%)$, and chronic obstructive pulmonary disease (7.26\% vs $5 \%$ ) (Table 1 ). Accordingly, the use of cardioprotective drugs at baseline such as blood pressure lowering, lipid lowering drugs, antiplatelet and anticoagulant agents were present more often among patients with diabetes. Laboratory findings showed a higher level of white cell count and $\mathrm{C}$ - reactive protein in patients with diabetes than those without diabetes. Glomerular filtration rate was lower in diabetes group. Prevalence of severe lung injury was slightly but not significantly higher in patients with diabetes compared to those without diabetes ( $21.8 \%$ vs $18.4 \%$ respectively) (Table 1). The use of pharmacological agents during follow-up was similar in patients with and without diabetes except for therapeutic-dose anticoagulation which was more often prescribed in patients with diabetes (21.9\% vs $17.4 \%)$ (Table 2$)$.

\section{Outcomes in the unmatched and the matched cohorts}

During a median follow-up of 19.0 [6.0;27.0] days, the primary outcome occurred in 830 (29.1\%) patients, including 283 (10.0\%) patients who died without transfer in ICU and 547 (19.2\%) transferred in ICU. The overall rate of in-hospital death was $12.6 \%$ (358 patients) including 75 (2.6\%) deaths in ICU. At the end of the follow-up, 1979 (69.6\%) patients were discharged and 507 (17.8\%) were still hospitalized.

Compared to patients without diabetes, those with diabetes had shorter durations from admission to occurrence of primary outcome (15.0 days [4.0;25.0] vs. 20.0 days [7.0;27.0] respectively; $p<0.001)$ but not from admission to death (7.0 days [4.0;11.0]) vs 7.0 days [4.0;11.0]; $p=0.63)$. The primary outcome occurred in $584(36.4 \%)$ patients with diabetes compared to $246(26.8 \%)$ in those without diabetes ( $<<0.001)$. We also observed a significant higher rate of secondary outcomes (overall mortality, transfer in ICU, invasive mechanical ventilation) in patients with diabetes versus those without ( $p<0.05$ for all) (Table 2). The Kaplan-Meier survival curves for primary outcome and overall mortality according to diabetic status are presented in Supplemental Figure S1. The crude cox proportional hazard model showed a significant higher risk of primary outcome and overall mortality in patients with diabetes compared with those without (HR 1.44 [95\% $\mathrm{Cl} 1.24-$ 1.67] for the primary outcome) (Supplemental Table S3).

PSM analysis was further performed to avoid confounding variables that could have interfered with the association between outcomes and diabetic status. After PSM, characteristics between groups were better balanced with no significant difference between patients with and without diabetes (Table 1).

As shown in Supplemental Table S2, in the PSM cohort, patients who experienced primary outcome, compared with those who did not, had more often diabetes and diabetes related comorbidities such as hypertension, diabetes, dyslipidemia, chronic kidney disease, history of cardiovascular disease and heart failure.

The incidence of the primary outcome was not statistically different between the two groups. Indeed, primary outcomes occurred in 214 (35.5\%) patients with diabetes versus 192 (31.8\%) (OR 1.18, 95\% Cl $0.93-1.50 ; p=0.20)$ (Table 2). No differences regarding the secondary outcomes were found between patients with and without diabetes. In-hospital death during follow-up encountered in 111 (18.4\%) patients with diabetes compared to 91 (15.1\%) patients without diabetes (OR 1.27, 95\%Cl $0.94-1.72 ; p=0.14$ ). Figure 2 showed the survival curves for primary outcome and overall mortality in patients with and without diabetes. Cox proportional hazards survival regression analyses did not show any significant association between diabetes and the incidence of either the primary outcome $(\mathrm{HR} 1.16,95 \% \mathrm{Cl} 0.95-1.41$, $\mathrm{p}=0.14)$ or each of the secondary outcome (Table 3).

\section{Sensitivity analysis}

As sensitivity analysis, we compared the incidence of outcomes in diabetes and non-diabetes groups in two other PSM cohorts (one including personal characteristics and comorbidities and one including admission vitals and laboratory findings) to better assess the impact of each type of covariates on the association between diabetes and events. In the first PSM cohort in which patients with and without diabetes were matched based on their personal characteristics and comorbidities, no difference was found for vital signs, laboratory and radiological findings between both groups (Supplemental Table S4). In the second PSM, including for matching vital signs and biological findings only, patients with diabetes were older, more frequently male, had a higher BMI and a higher prevalence of comorbidities as observed in the unmatched cohort. Cox regression analysis showed that in both PSM cohorts, associations between diabetes status and risk of severe outcomes were non-significant (Supplemental Table S5). 


\section{Discussion}

In this cohort of 2,851 patients hospitalized for COVID-19, we observed a higher risk for worse outcomes in people with diabetes compared with those without diabetes. However, we found that in subset analyses of 1,206 propensity score matched patients for all confounding covariates, diabetes per se did not significantly increase risk of severe outcomes.

Since the beginning of the COVID-19 pandemic in January 2020, there was growing evidence from descriptive and epidemiological studies showing a higher prevalence of diabetes in severe COVID-19. Indeed, prevalence of diabetes varied from 17 to $37 \%$ in the most recent case series of hospitalized patients in US or Europe $(2,3,15-17)$. In the present study, we report a similar rate of $23.6 \%$ subjects with diabetes among patients hospitalized for COVID-19. Similarly, we also observed a high rate of associated comorbidities with hypertension being the most frequent of them followed by cardiovascular diseases, chronic respiratory disease and chronic kidney disease. As already reported, all these comorbidities were 2-3-fold higher in patients with diabetes compared with those without diabetes. We also found that in the unmatched cohort, patients with diabetes were more prone to receive invasive mechanical ventilation and intensive care and had higher mortality than those without diabetes (9-11).

Despite several case series of patients hospitalized for COVID-19 worldwide, few researches have been specifically focused on the prognosis of patients with and without diabetes. In contrast with our results, these studies have shown that diabetes was associated with a higher risk of severe outcomes. Zhu $L$ et al reported a significant 1.49 higher risk for all-cause mortality between groups in a retrospective study of 7,337 patients (952 with type 2 diabetes) hospitalized in China for COVID-19 (11). However, they did not adjust for comorbidities closely related to type 2 diabetes such as hypertension, cardiovascular diseases, and chronic kidney disease while all have been shown to be major risk factors in COVID-19 prognosis (15). Another Chinese retrospective study in a small number of subjects (193 patients, 48 with diabetes) found that patients with diabetes had a lower survival rate than patients without diabetes with a hazard ratio of $1.53(p=0.041)$ after adjustment for age, sex, hypertension, cardiovascular disease and cerebrovascular disease (10). Similarly, in a preprint version of a nationwide study of 23,804 COVID-19 related deaths in England, the odds ratio for dying in-hospital with COVID-19 in people with type 2 diabetes was 1.81 higher compared to the population without known diabetes (18). Despite its large number of participants, some important potential cofounding comorbidities such as hypertension and chronic kidney disease were lacking in this study. Moreover, since time-to-event data were not available in this preprint, it might negatively impact robustness of the results.

Compared with already mentioned studies, we used PSM analysis to avoid the confounding effect of comorbidities frequently associated both with diabetes and worse outcomes in COVID-19 and found that diabetes is no longer significantly associated with a higher risk of severe outcomes. In accordance with our results, a recent study of 20,133 UK patients in hospital for COVID-19 has shown that while diabetes was common (28.1\%) in this population, the association of diabetes with mortality risk was attenuate to become non-significant after multiple adjustment in cox analysis (HR 1.06) (19). Similarly, in a study of 5,279 subjects in New-York City, Petrilli CM et al. found a 3.6-fold higher prevalence of diabetes in people with COVID-19 admitted to hospital compared with those not admitted (20). However, after multiple adjustment, risk of critical illness among inpatients with diabetes was similar than those without diabetes. Taken together, these findings suggest that the increased risk of severe outcomes reported in patients with diabetes is alleviated after adjustment for diabetes related comorbidities. Diabetes associated risk of severe outcomes in COVID-19 might be more driven by associated comorbidities than by diabetes itself.

In sensitivity analysis where vital signs and laboratory findings only were used to build the propensity score for matching, a similar risk of outcomes between diabetic and non-diabetic groups were found while patients with diabetes were older, had higher BMI and a higher rate of associated comorbidities. The interpretation of these findings was not obvious and subject to bias. However, it could be argued that differential risk between patients with and without diabetes might be driven by vital signs and biological findings rather than by clinical characteristics and comorbidities. In two previous studies comparing subjects with and without diabetes, cox regression analysis found a higher rate of outcomes in patients with diabetes after adjustment for age, sex, hypertension, cardiovascular disease and cerebrovascular disease but not for biochemical values despite significant difference in inflammatory markers between groups $(9,10)$. Moreover, in the study by Petrilli et al., the risk of severe outcomes was significantly higher when adjustment was made only for clinical characteristics and medical history but was no longer significant after adjusting for both previous comorbidities and biological findings at admission (20). Taken together, these data suggest that severity of the infection at admission rather than comorbidities were associated with worse outcomes.

Our study had some limitations. First, data regarding detailed diabetes characteristics which could influence outcomes such as $\mathrm{HbA1c}$, diabetes duration, diabetic therapies and microvascular complications were not available in this cohort. However, in the CORONADO study, a well-documented French cohort of 1,317 patients with diabetes hospitalized for COVID-19, Cariou et al. showed that BMI but not diabetes related patterns was positively and independently associated with tracheal intubation and/or death within 7 days (21). Nonetheless, a more obvious limitation here is the lack of data on glycemic control at admission or during hospitalization. Indeed, Wang et al. observed that in 605 patients without previous diagnosis of diabetes, fasting blood glucose at admission is an independent predictor for 28-day mortality in 
patients with COVID-19 (22). Furthermore, Zhu et al. have been shown that, among patients with type 2 diabetes, those with well-controlled blood glucose during hospital stay had better prognosis than those with poorly controlled glycemia (11). These data suggest than glycemic control at admission and during hospitalization could impact COVID-19 prognosis in patients with diabetes rather than glycemic control before or other specific patterns of diabetes. Third, data used here came from 24 centres where COVID-19 care strategies may differ between each center due to the urgent circumstance of the COVID-19 pandemic. Fourth, we cannot avoid classification bias due to the retrospective nature of the cohort. However, data were collected by the Critical Covid-19 France Investigators who were all first line doctors, directly in charge of participants and numbers of missing data are limited. Fifth, only data from patients hospitalized for COVID-19 were analyzed and our results cannot be generalized to COVID-19 people with a less severe form of the disease. Finally, since all hazard ratio found in PSM analysis were larger than 1 with wide confidence intervals, we cannot claim a null effect of diabetes on COVID-19 outcomes.

\section{Conclusion}

Our findings showed that, despite a high prevalence of diabetes among patients hospitalized for COVID-19, the risk of severe outcomes is mainly driven by associated comorbidities or a worse clinical presentation at admission. These results provide new insights in the risk stratification of patients with COVID-19. Further studies on a larger scale and well controlled for confounding bias are warranted to confirm these findings.

\section{Abbreviations}

Coronavirus disease 2019 (COVID-19)

Intensive care unit (ICU)

Propensity score matched (PSM)

Renin angiotensin system (RAS)

Severe acute respiratory syndrome coronavirus 2 (SARS-cov-2)

\section{Declarations}

\section{Ethics approval and consent to participate}

The CCF study was declared to and authorized by the French data protection committee (Commission Nationale Informatique et Liberté, CNIL, authorization $\mathrm{n}^{\circ} 2207326 \mathrm{v} 0$ ), and was conducted in accordance with the ethical standards laid down in the 1964 Declaration of Helsinki and its later amendments.

\section{Consent for publication}

Not applicable

\section{Availability of data and materials}

The datasets used and/or analyzed during the current study are available from the corresponding author on reasonable request.

\section{Competing interests}

LP reports grants, personal fees and non-financial support from Novo Nordisk, MSD and Sanofi, personal fees and non-financial support from Eli Lilly and non-financial support from Servier. AC acknowledges the following without any relationship to the current manuscript: research grant from RESICARD (research nurses); and consultant and lecture fees from the companies Amgen, AstraZeneca, Bayer Pharma, Alliance BMS-Pfizer, Novartis, and Sanofi-Aventis. The other authors have nothing to declare

\section{Funding}

This research did not receive any specific grant from funding agencies in the public, commercial, or not-for-profit sectors.

\section{Authors' contributions}

LP and WS had full access to all of the data in the study and take responsibility for the integrity of the data and the accuracy of the data analysis. Study concept and design: LP, WS, Acquisition, analysis, or interpretation of data: All authors. Drafting of the manuscript: LP, WS. 
Critical revision of the manuscript for important intellectual content: all authors. Final approval of the version to be published: All authors. The corresponding author attests that all listed authors meet authorship criteria and that no others meeting the criteria have been omitted.

\section{Acknowledgements}

We thank the medical and paramedical staff involved in the care of patients in this period; all members of the French Society of Cardiology

\section{References}

1. Zhou F, Yu T, Du R, Fan G, Liu Y, Liu Z, et al. Clinical course and risk factors for mortality of adult inpatients with COVID-19 in Wuhan, China: a retrospective cohort study. Lancet. 2020;395(10229):1054-62.

2. Argenziano MG, Bruce SL, Slater CL, Tiao JR, Baldwin MR, Barr RG, et al. Characterization and clinical course of 1000 patients with coronavirus disease 2019 in New York: retrospective case series. BMJ. 2020;369:m1996.

3. Onder G, Rezza G, Brusaferro S. Case-Fatality Rate and Characteristics of Patients Dying in Relation to COVID-19 in Italy. JAMA. 2020.

4. Wu Z, McGoogan JM. Characteristics of and Important Lessons From the Coronavirus Disease 2019 (COVID-19) Outbreak in China: Summary of a Report of 72314 Cases From the Chinese Center for Disease Control and Prevention. JAMA. 2020.

5. Caussy C, Pattou F, Wallet F, Simon C, Chalopin S, Telliam C, et al. Prevalence of obesity among adult inpatients with COVID-19 in France. Lancet Diabetes Endocrinol. 2020;8(7):562-4.

6. Gao C, Cai Y, Zhang K, Zhou L, Zhang Y, Zhang X, et al. Association of hypertension and antihypertensive treatment with COVID-19 mortality: a retrospective observational study. Eur Heart J. 2020;41(22):2058-66.

7. Shi S, Qin M, Shen B, Cai Y, Liu T, Yang F, et al. Association of Cardiac Injury With Mortality in Hospitalized Patients With COVID-19 in Wuhan, China. JAMA Cardiol. 2020.

8. Yamada T, Mikami T, Chopra N, Miyashita H, Chernyavsky S, Miyashita S. Patients with chronic kidney disease have a poorer prognosis of coronavirus disease 2019 (COVID-19): an experience in New York City. Int Urol Nephrol. 2020.

9. Shi Q, Zhang X, Jiang F, Zhang X, Hu N, Bimu C, et al. Clinical Characteristics and Risk Factors for Mortality of COVID-19 Patients With Diabetes in Wuhan, China: A Two-Center, Retrospective Study. Diabetes Care. 2020;43(7):1382-91.

10. Yan Y, Yang Y, Wang F, Ren H, Zhang S, Shi X, et al. Clinical characteristics and outcomes of patients with severe covid-19 with diabetes. BMJ Open Diabetes Res Care. 2020;8(1).

11. Zhu L, She ZG, Cheng X, Qin JJ, Zhang XJ, Cai J, et al. Association of Blood Glucose Control and Outcomes in Patients with COVID-19 and Pre-existing Type 2 Diabetes. Cell Metab. 2020;31(6):1068-77 e3.

12. Fauvel C, Weizman O, Trimaille A, Mika D, Pommier T, Pace N, et al. Pulmonary embolism in COVID-19 patients: a French multicentre cohort study. Eur Heart J. 2020.

13. von Elm E, Altman DG, Egger M, Pocock SJ, Gotzsche PC, Vandenbroucke JP, et al. Strengthening the Reporting of Observational Studies in Epidemiology (STROBE) statement: guidelines for reporting observational studies. BMJ. 2007;335(7624):806-8.

14. Austin PC. An Introduction to Propensity Score Methods for Reducing the Effects of Confounding in Observational Studies. Multivariate Behav Res. 2011;46(3):399-424.

15. Cummings MJ, Baldwin MR, Abrams D, Jacobson SD, Meyer BJ, Balough EM, et al. Epidemiology, clinical course, and outcomes of critically ill adults with COVID-19 in New York City: a prospective cohort study. Lancet. 2020;395(10239):1763-70.

16. Grasselli G, Zangrillo A, Zanella A, Antonelli M, Cabrini L, Castelli A, et al. Baseline Characteristics and Outcomes of 1591 Patients Infected With SARS-CoV-2 Admitted to ICUs of the Lombardy Region, Italy. JAMA. 2020.

17. Richardson S, Hirsch JS, Narasimhan M, Crawford JM, McGinn T, Davidson KW, et al. Presenting Characteristics, Comorbidities, and Outcomes Among 5700 Patients Hospitalized With COVID-19 in the New York City Area. JAMA. 2020.

18. Type 1 and Type 2 diabetes and COVID-19 related mortality in England: a whole population study [press release]. 2020.

19. Docherty AB, Harrison EM, Green CA, Hardwick HE, Pius R, Norman L, et al. Features of 20133 UK patients in hospital with covid-19 using the ISARIC WHO Clinical Characterisation Protocol: prospective observational cohort study. BMJ. 2020;369:m1985.

20. Petrilli CM, Jones SA, Yang J, Rajagopalan H, O'Donnell L, Chernyak Y, et al. Factors associated with hospital admission and critical illness among 5279 people with coronavirus disease 2019 in New York City: prospective cohort study. BMJ. 2020;369:m1966.

21. Cariou B, Hadjadj S, Wargny M, Pichelin M, Al-Salameh A, Allix I, et al. Phenotypic characteristics and prognosis of inpatients with COVID19 and diabetes: the CORONADO study. Diabetologia. 2020.

22. Wang S, Ma P, Zhang S, Song S, Wang Z, Ma Y, et al. Fasting blood glucose at admission is an independent predictor for 28-day mortality in patients with COVID-19 without previous diagnosis of diabetes: a multi-centre retrospective study. Diabetologia. 2020. 


\section{Tables}

Table 1: Patients Characteristics at admission according to diabetic status before and after PSM 


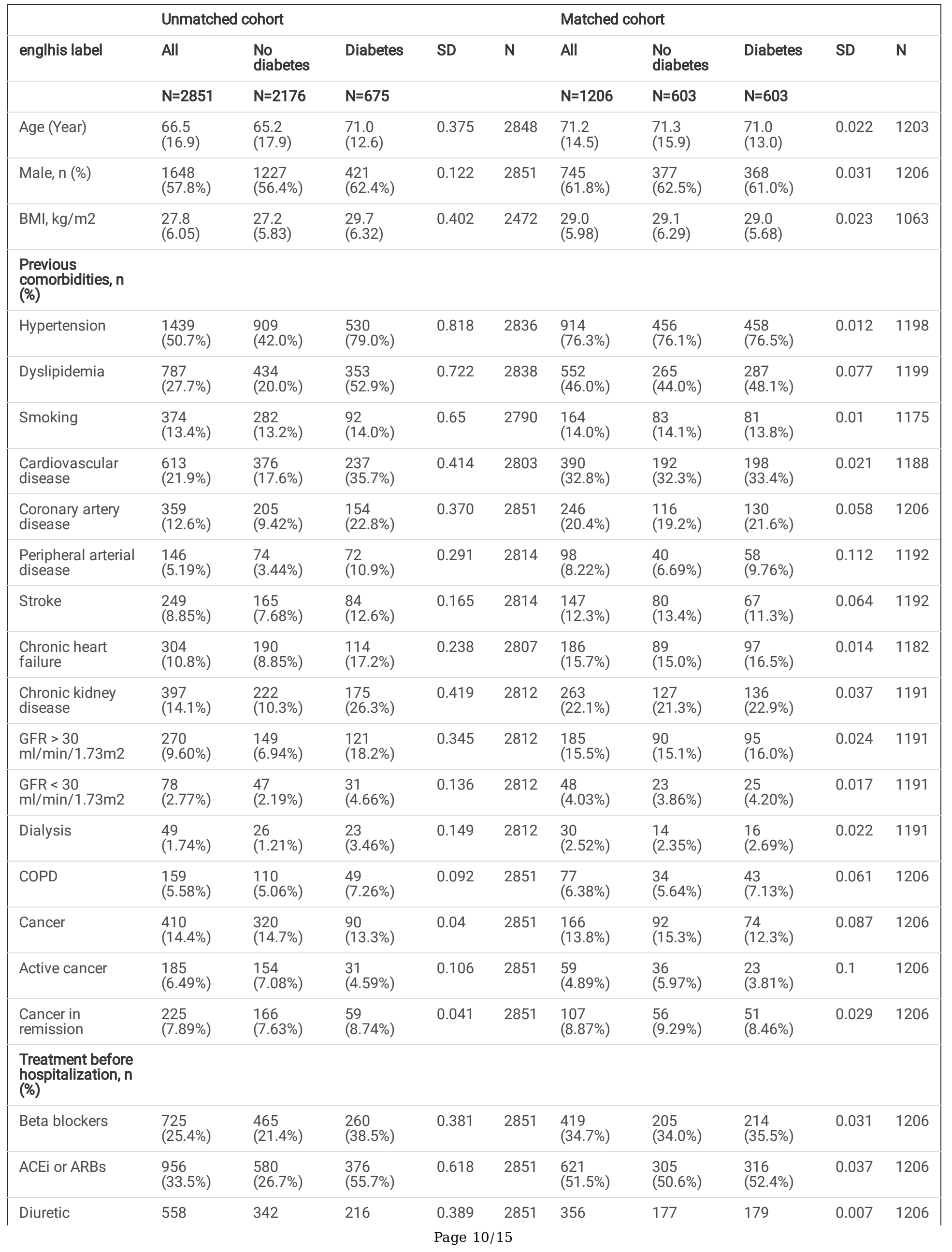




\begin{tabular}{|c|c|c|c|c|c|c|c|c|c|c|}
\hline & (19.6\%) & $(15.7 \%)$ & $(32.0 \%)$ & & & $(29.5 \%)$ & $(29.4 \%)$ & $(29.7 \%)$ & & \\
\hline Statin & $\begin{array}{l}644 \\
(22.6 \%)\end{array}$ & $\begin{array}{l}350 \\
(16.1 \%)\end{array}$ & $\begin{array}{l}294 \\
(43.6 \%)\end{array}$ & 0.63 & 2851 & $\begin{array}{l}446 \\
(37.0 \%)\end{array}$ & $\begin{array}{l}202 \\
(33.5 \%)\end{array}$ & $\begin{array}{l}244 \\
(40.5 \%)\end{array}$ & 0.145 & 1206 \\
\hline $\begin{array}{l}\text { Antiplatelet } \\
\text { agents }\end{array}$ & $\begin{array}{l}621 \\
(21.8 \%)\end{array}$ & $\begin{array}{l}355 \\
(16.3 \%)\end{array}$ & $\begin{array}{l}266 \\
(39.4 \%)\end{array}$ & 0.533 & 2851 & $\begin{array}{l}405 \\
(33.6 \%)\end{array}$ & $\begin{array}{l}179 \\
(29.7 \%)\end{array}$ & $\begin{array}{l}226 \\
(37.5 \%)\end{array}$ & 0.166 & 1206 \\
\hline Anticoagulation & $\begin{array}{l}412 \\
(14.5 \%)\end{array}$ & $\begin{array}{l}295 \\
(13.6 \%)\end{array}$ & $\begin{array}{l}117 \\
(17.3 \%)\end{array}$ & 0.105 & 2851 & $\begin{array}{l}224 \\
(18.6 \%)\end{array}$ & $\begin{array}{l}123 \\
(20.4 \%)\end{array}$ & $\begin{array}{l}101 \\
(16.7 \%)\end{array}$ & 0.094 & 1206 \\
\hline \multicolumn{11}{|l|}{$\begin{array}{l}\text { Clinical } \\
\text { characteristics at } \\
\text { admission }\end{array}$} \\
\hline $\begin{array}{l}\text { Time from illness } \\
\text { onset to } \\
\text { hospitalization, } \\
\text { days }\end{array}$ & $6.8(4.7)$ & $6.9(4.6)$ & $6.4(4.8)$ & 0.119 & 2753 & $6.5(4.8)$ & $6.7(4.8)$ & $6.3(4.7)$ & 0.081 & 1160 \\
\hline \multirow[t]{2}{*}{ Fever } & $\begin{array}{l}286 \\
(10.2 \%)\end{array}$ & $\begin{array}{l}228 \\
(10.6 \%)\end{array}$ & $\begin{array}{l}58 \\
(8.79 \%)\end{array}$ & 0.062 & 2805 & $\begin{array}{l}117 \\
(9.89 \%)\end{array}$ & $\begin{array}{l}69 \\
(11.6 \%)\end{array}$ & $\begin{array}{l}48 \\
(8.15 \%)\end{array}$ & 0.116 & 1183 \\
\hline & & & & & & & & & 0.061 & \\
\hline Heart rate, bpm & $\begin{array}{l}86.7 \\
(17.9)\end{array}$ & $\begin{array}{l}86.6 \\
(17.8)\end{array}$ & $\begin{array}{l}86.8 \\
(18.3)\end{array}$ & 0.07 & 2601 & $\begin{array}{l}86.5 \\
(18.6)\end{array}$ & $\begin{array}{l}85.9 \\
(19.2)\end{array}$ & $\begin{array}{l}87.0 \\
(17.9)\end{array}$ & 0.037 & 1096 \\
\hline $\begin{array}{l}\text { Systolic blood } \\
\text { pressure, mmHg }\end{array}$ & $131(22.0)$ & $130(21.4)$ & $135(23.4)$ & 0.234 & 2803 & $134(22.7)$ & $134(22.4)$ & 135 (23.0) & 0.069 & 1186 \\
\hline $\begin{array}{l}\text { Diastolic blood } \\
\text { pressure, mmHg }\end{array}$ & $\begin{array}{l}74.3 \\
(13.4)\end{array}$ & $\begin{array}{l}74.3 \\
(13.3)\end{array}$ & $\begin{array}{l}74.2 \\
(13.8)\end{array}$ & 0.008 & 2803 & $\begin{array}{l}74.9 \\
(13.5)\end{array}$ & $\begin{array}{l}75.4 \\
(13.3)\end{array}$ & $\begin{array}{l}74.4 \\
(13.8)\end{array}$ & 0.067 & 1186 \\
\hline $\begin{array}{l}\text { Respiratory } \\
\text { frequency, cpm }\end{array}$ & $23.4(6.6)$ & $23.3(6.7)$ & $23.4(6.2)$ & 0.01 & 2093 & $23.6(6.4)$ & $23.8(6.7)$ & $23.4(6.1)$ & 0.009 & 892 \\
\hline O2 Saturation, \% & 94.7 (3.6) & $94.8(3.6)$ & $94.4(3.6)$ & 0.134 & 2827 & 94.5 (3.7) & $94.5(3.9)$ & $94.5(3.4)$ & 0.013 & 1194 \\
\hline $\mathrm{FiO} 2, \%$ & $\begin{array}{l}28.6 \\
(12.1)\end{array}$ & $\begin{array}{l}28.4 \\
(12.0)\end{array}$ & $\begin{array}{l}29.1 \\
(12.4)\end{array}$ & 0.055 & 2757 & $\begin{array}{l}28.9 \\
(12.4)\end{array}$ & $\begin{array}{l}28.9 \\
(12.5)\end{array}$ & $\begin{array}{l}29.0 \\
(12.3)\end{array}$ & 0.043 & 1162 \\
\hline $\begin{array}{l}\text { Withdrawal of } \\
\text { life-sustaining } \\
\text { therapy, } n(\%)\end{array}$ & $\begin{array}{l}580 \\
(21.0 \%)\end{array}$ & $\begin{array}{l}421 \\
(20.0 \%)\end{array}$ & $\begin{array}{l}159 \\
(24.2 \%)\end{array}$ & 0.097 & 2761 & $\begin{array}{l}287 \\
(24.6 \%)\end{array}$ & $\begin{array}{l}137 \\
(23.7 \%)\end{array}$ & $\begin{array}{l}150 \\
(25.4 \%)\end{array}$ & 0.081 & 1169 \\
\hline \multicolumn{11}{|l|}{$\begin{array}{l}\text { Laboratory } \\
\text { findings at } \\
\text { admission, mean } \\
\text { (SD) }\end{array}$} \\
\hline Hemoglobin, g/dL & $\begin{array}{l}13.3 \\
{[11.9 ; 14.5]}\end{array}$ & $\begin{array}{l}13.4 \\
{[12.1 ; 14.6]}\end{array}$ & $\begin{array}{l}12.9 \\
{[11.5 ; 14.2]}\end{array}$ & 0.226 & 2808 & $\begin{array}{l}13.1 \\
{[11.7 ; 14.3]}\end{array}$ & $\begin{array}{l}13.3 \\
{[11.8 ; 14.5]}\end{array}$ & $\begin{array}{l}13.0 \\
{[11.6 ; 14.2]}\end{array}$ & 0.081 & 1196 \\
\hline Platelet, G/L & $\begin{array}{l}199 \\
{[155 ; 265]}\end{array}$ & $\begin{array}{l}197 \\
{[155 ; 263]}\end{array}$ & $\begin{array}{l}205 \\
{[156 ; 276]}\end{array}$ & 0.084 & 2780 & $\begin{array}{l}195 \\
{[154 ; 264]}\end{array}$ & $\begin{array}{l}188 \\
{[153 ; 257]}\end{array}$ & $\begin{array}{l}203 \\
{[155 ; 275]}\end{array}$ & 0.116 & 1182 \\
\hline $\begin{array}{l}\text { White cell count, } \\
/ \mathrm{mL}\end{array}$ & $\begin{array}{l}6.38 \\
{[4.80 ; 8.70]}\end{array}$ & $\begin{array}{l}6.26 \\
{[4.70 ; 8.61]}\end{array}$ & $\begin{array}{l}6.70 \\
{[5.10 ; 9.00]}\end{array}$ & 0.057 & 2800 & $\begin{array}{l}6.50 \\
{[4.95 ; 9.00]}\end{array}$ & $\begin{array}{l}6.46 \\
{[4.88 ; 9.10]}\end{array}$ & $\begin{array}{l}6.60 \\
{[5.02 ; 8.95]}\end{array}$ & 0.061 & 1190 \\
\hline $\begin{array}{l}\text { Lymphocyte } \\
\text { count, /mL }\end{array}$ & $\begin{array}{l}0.95 \\
{[0.70 ; 1.33]}\end{array}$ & $\begin{array}{l}0.95 \\
{[0.70 ; 1.33]}\end{array}$ & $\begin{array}{l}0.97 \\
{[0.69 ; 1.33]}\end{array}$ & 0.036 & 2759 & $\begin{array}{l}0.96 \\
{[0.69 ; 1.32]}\end{array}$ & $\begin{array}{l}0.93 \\
{[0.69 ; 1.30]}\end{array}$ & $\begin{array}{l}0.98 \\
{[0.70 ; 1.33]}\end{array}$ & 0.037 & 1170 \\
\hline $\begin{array}{l}\text { Creatinine, } \\
\mu \mathrm{mol} / \mathrm{L}\end{array}$ & $\begin{array}{l}77.0 \\
{[61.0 ; 101]}\end{array}$ & $\begin{array}{l}75.0 \\
{[60.0 ; 94.0]}\end{array}$ & $\begin{array}{l}88.0 \\
{[65.0 ; 129]}\end{array}$ & $<0.001$ & 2807 & $\begin{array}{l}85.0 \\
{[66.0 ; 119]}\end{array}$ & $\begin{array}{l}85.0 \\
{[67.9 ; 116]}\end{array}$ & $\begin{array}{l}84.0 \\
{[64.0 ; 122]}\end{array}$ & 0.069 & 1190 \\
\hline $\begin{array}{l}\text { GFR, } \\
\mathrm{mL} / \mathrm{min} / 1.73 \mathrm{~m}^{2}\end{array}$ & $\begin{array}{l}84.6 \\
{[61.4 ; 106]}\end{array}$ & $\begin{array}{l}87.2 \\
{[67.1 ; 108]}\end{array}$ & $\begin{array}{l}73.3 \\
{[46.1 ; 98.7]}\end{array}$ & 0.417 & 2804 & $\begin{array}{l}76.0 \\
{[50.7 ; 98.6]}\end{array}$ & $\begin{array}{l}75.4 \\
{[52.6 ; 94.9]}\end{array}$ & $\begin{array}{l}77.1 \\
{[49.4 ; 101]}\end{array}$ & 0.067 & 1187 \\
\hline $\begin{array}{l}\text { Alanine } \\
\text { aminotransferase, } \\
\text { UI/L }\end{array}$ & $\begin{array}{l}31.0 \\
{[21.0 ; 52.0]}\end{array}$ & $\begin{array}{l}32.0 \\
{[22.0 ; 53.0]}\end{array}$ & $\begin{array}{l}30.0 \\
{[21.0 ; 48.0]}\end{array}$ & 0.041 & 2591 & $\begin{array}{l}31.0 \\
{[21.0 ; 49.0]}\end{array}$ & $\begin{array}{l}33.0 \\
{[22.0 ; 51.0]}\end{array}$ & $\begin{array}{l}30.0 \\
{[21.0 ; 48.0]}\end{array}$ & 0.009 & 1101 \\
\hline $\begin{array}{l}\text { Aspartate } \\
\text { aminotransferase, } \\
\text { UI/L }\end{array}$ & $\begin{array}{l}39.0 \\
{[26.0 ; 60.0]}\end{array}$ & $\begin{array}{l}39.0 \\
{[27.0 ; 61.0]}\end{array}$ & $\begin{array}{l}36.0 \\
{[26.0 ; 55.0]}\end{array}$ & 0.023 & 2585 & $\begin{array}{l}39.0 \\
{[27.0 ; 60.0]}\end{array}$ & $\begin{array}{l}41.0 \\
{[27.0 ; 64.0]}\end{array}$ & $\begin{array}{l}37.0 \\
{[26.0 ; 55.0]}\end{array}$ & 0.013 & 1097 \\
\hline $\begin{array}{l}\text { bilirubinemia, } \\
\mathrm{mg} / \mathrm{L}\end{array}$ & $\begin{array}{l}9.00 \\
{[6.20 ; 12.0]}\end{array}$ & $\begin{array}{l}9.00 \\
{[6.10 ; 12.0]}\end{array}$ & $\begin{array}{l}9.00 \\
{[6.57 ; 12.0]}\end{array}$ & 0.105 & 2404 & $\begin{array}{l}9.00 \\
{[6.80 ; 12.6]}\end{array}$ & $\begin{array}{l}9.00 \\
{[6.80 ; 13.0]}\end{array}$ & $\begin{array}{l}9.00 \\
{[6.70 ; 12.0]}\end{array}$ & 0.043 & 1018 \\
\hline
\end{tabular}




\begin{tabular}{|c|c|c|c|c|c|c|c|c|c|c|}
\hline gamma GT, UI/L & $\begin{array}{l}53.0 \\
{[30.0 ; 99.0]}\end{array}$ & $\begin{array}{l}53.0 \\
{[30.0 ; 101]}\end{array}$ & $\begin{array}{l}53.0 \\
{[30.0 ; 91.0]}\end{array}$ & 0.001 & 2278 & $\begin{array}{l}54.0 \\
{[31.0 ; 100]}\end{array}$ & $\begin{array}{l}56.0 \\
{[32.0 ; 112]}\end{array}$ & $\begin{array}{l}52.0 \\
{[30.0 ; 90.0]}\end{array}$ & 0.081 & 978 \\
\hline $\begin{array}{l}\text { C-reactive protein, } \\
\mathrm{mg} / \mathrm{L}\end{array}$ & $\begin{array}{l}71.0 \\
{[30.1 ; 130]}\end{array}$ & $\begin{array}{l}69.0 \\
{[28.1 ; 129]}\end{array}$ & $\begin{array}{l}76.0 \\
{[34.8 ; 130]}\end{array}$ & 0.061 & 2732 & $\begin{array}{l}76.2 \\
{[35.2 ; 133]}\end{array}$ & $\begin{array}{l}77.0 \\
{[38.1 ; 138]}\end{array}$ & $\begin{array}{l}75.7 \\
{[34.0 ; 128]}\end{array}$ & 0.116 & 1159 \\
\hline D-dimer, $\mu \mathrm{g} / \mathrm{L}$ & $\begin{array}{l}851 \\
{[364 ; 1725]}\end{array}$ & $\begin{array}{l}830 \\
{[360 ; 1710]}\end{array}$ & $\begin{array}{l}980 \\
{[411 ; 1738]}\end{array}$ & 0.021 & 1150 & $\begin{array}{l}970 \\
{[416 ; 1860]}\end{array}$ & $\begin{array}{l}980 \\
{[470 ; 1910]}\end{array}$ & $\begin{array}{l}955 \\
{[363 ; 1754]}\end{array}$ & 0.061 & 463 \\
\hline $\mathrm{PaO} 2, \mathrm{mmHg}$ & $\begin{array}{l}73.5 \\
{[64.7 ; 89.0]}\end{array}$ & $\begin{array}{l}74.0 \\
{[65.0 ; 90.0]}\end{array}$ & $\begin{array}{l}71.9 \\
{[63.6 ; 88.0]}\end{array}$ & 0.032 & 2000 & $\begin{array}{l}73.0 \\
{[64.0 ; 88.0]}\end{array}$ & $\begin{array}{l}74.0 \\
{[65.0 ; 89.0]}\end{array}$ & $\begin{array}{l}72.0 \\
{[64.0 ; 88.0]}\end{array}$ & 0.037 & 873 \\
\hline \multicolumn{11}{|l|}{$\begin{array}{l}\text { Parenchymal } \\
\text { involvement on } \\
\text { Computed } \\
\text { tomography, n (\%) }\end{array}$} \\
\hline Low (<30 \%) & $\begin{array}{l}945 \\
(42.4 \%)\end{array}$ & $\begin{array}{l}738 \\
(43.4 \%)\end{array}$ & $\begin{array}{l}207 \\
(39.3 \%)\end{array}$ & 0.804 & 2227 & $\begin{array}{l}382 \\
(40.6 \%)\end{array}$ & $\begin{array}{l}200 \\
(42.9 \%)\end{array}$ & $\begin{array}{l}182 \\
(38.3 \%)\end{array}$ & 0.094 & 941 \\
\hline $\begin{array}{l}\text { Moderate (30-50 } \\
\%)\end{array}$ & $\begin{array}{l}855 \\
(38.4 \%)\end{array}$ & $\begin{array}{l}650 \\
(38.2 \%)\end{array}$ & $\begin{array}{l}205 \\
(38.9 \%)\end{array}$ & 0.014 & 2227 & $\begin{array}{l}348 \\
(37.0 \%)\end{array}$ & $\begin{array}{l}163 \\
(35.0 \%)\end{array}$ & $\begin{array}{l}185 \\
(38.9 \%)\end{array}$ & 0.082 & 941 \\
\hline Severe (> $50 \%)$ & $\begin{array}{l}427 \\
(19.2 \%)\end{array}$ & $\begin{array}{l}312 \\
(18.4 \%)\end{array}$ & $\begin{array}{l}115 \\
(21.8 \%)\end{array}$ & 0.087 & 2227 & $\begin{array}{l}211 \\
(22.4 \%)\end{array}$ & $\begin{array}{l}103 \\
(22.1 \%)\end{array}$ & $\begin{array}{l}108 \\
(22.7 \%)\end{array}$ & 0.015 & 941 \\
\hline
\end{tabular}

Data are presented as numbers (\%) and mean \pm SD, or median (25th; 75th percentile) if not normally distributed.

COPD : chronic obstructive pulmonary disease, ACEl : angiotensin converting enzyme inhibitors, ARB : angiotensin receptor blockers, GFR: glomerular filtration rate.

Table 2: Treatments and clinical outcomes during follow-up according diabetic status in unmatched cohort and matched cohort 


\begin{tabular}{|c|c|c|c|c|c|c|c|c|c|c|}
\hline & \multicolumn{5}{|c|}{ Unmatched cohort } & \multicolumn{3}{|c|}{ Matched cohort } & \multirow[b]{2}{*}{ p } & \multirow[b]{2}{*}{$\mathbf{N}$} \\
\hline & All & $\begin{array}{l}\text { No } \\
\text { diabetes }\end{array}$ & Diabetes & $\mathbf{p}$ & $\mathbf{N}$ & All & $\begin{array}{l}\text { No } \\
\text { diabetes }\end{array}$ & Diabetes & & \\
\hline \multicolumn{11}{|c|}{ Treatment introduced during hospitalization n (\%) } \\
\hline $\begin{array}{l}\text { Chloroquine or } \\
\text { hydroxychloroquine }\end{array}$ & $\begin{array}{l}498 \\
(17.5 \%)\end{array}$ & $\begin{array}{l}386 \\
(17.7 \%)\end{array}$ & $\begin{array}{l}112 \\
(16.6 \%)\end{array}$ & 0.53 & 2851 & $\begin{array}{l}197 \\
(16.3 \%)\end{array}$ & $\begin{array}{l}97 \\
(16.1 \%)\end{array}$ & $\begin{array}{l}100 \\
(16.6 \%)\end{array}$ & 0.88 & 1206 \\
\hline Antiviral & $\begin{array}{l}377 \\
(13.2 \%)\end{array}$ & $\begin{array}{l}286 \\
(13.1 \%)\end{array}$ & $\begin{array}{l}91 \\
(13.5 \%)\end{array}$ & 0.87 & 2851 & $\begin{array}{l}148 \\
(12.3 \%)\end{array}$ & $\begin{array}{l}70 \\
(11.6 \%)\end{array}$ & $\begin{array}{l}78 \\
(12.9 \%)\end{array}$ & 0.54 & 1206 \\
\hline Corticosteroids & $\begin{array}{l}214 \\
(7.51 \%)\end{array}$ & $\begin{array}{l}172 \\
(7.90 \%)\end{array}$ & $\begin{array}{l}42 \\
(6.22 \%)\end{array}$ & 0.17 & 2851 & $\begin{array}{l}93 \\
(7.71 \%)\end{array}$ & $\begin{array}{l}53 \\
(8.79 \%)\end{array}$ & $\begin{array}{l}40 \\
(6.63 \%)\end{array}$ & 0.20 & 1206 \\
\hline Antibiotics & $\begin{array}{l}2121 \\
(74.4 \%)\end{array}$ & $\begin{array}{l}1603 \\
(73.7 \%)\end{array}$ & $\begin{array}{l}518 \\
(76.7 \%)\end{array}$ & 0.12 & 2851 & $\begin{array}{l}915 \\
(75.9 \%)\end{array}$ & $\begin{array}{l}453 \\
(75.1 \%)\end{array}$ & $\begin{array}{l}462 \\
(76.6 \%)\end{array}$ & 0.59 & 1206 \\
\hline Anticoagulation & $\begin{array}{l}2330 \\
(87.4 \%)\end{array}$ & $\begin{array}{l}1753 \\
(86.4 \%)\end{array}$ & $\begin{array}{l}577 \\
(90.7 \%)\end{array}$ & 0.005 & 2665 & $\begin{array}{l}1020 \\
(90.5 \%)\end{array}$ & $\begin{array}{l}503 \\
(90.1 \%)\end{array}$ & $\begin{array}{l}517 \\
(90.9 \%)\end{array}$ & 0.76 & 1127 \\
\hline Prophylaxis-dose & $\begin{array}{l}1803 \\
(67.7 \%)\end{array}$ & $\begin{array}{l}1374 \\
(67.7 \%)\end{array}$ & $\begin{array}{l}429 \\
(67.5 \%)\end{array}$ & 0.94 & 2665 & $\begin{array}{l}751 \\
(66.6 \%)\end{array}$ & $\begin{array}{l}359 \\
(64.3 \%)\end{array}$ & $\begin{array}{l}392 \\
(68.9 \%)\end{array}$ & 0.12 & 1127 \\
\hline Curative-dose & $\begin{array}{l}527 \\
(19.8 \%)\end{array}$ & $\begin{array}{l}379 \\
(18.7 \%)\end{array}$ & $\begin{array}{l}148 \\
(23.3 \%)\end{array}$ & 0.013 & 2665 & $\begin{array}{l}269 \\
(23.9 \%)\end{array}$ & $\begin{array}{l}144 \\
(25.8 \%)\end{array}$ & $\begin{array}{l}125 \\
(22.0 \%)\end{array}$ & 0.15 & 1127 \\
\hline \multicolumn{11}{|l|}{ Respiratory support } \\
\hline Low-dose oxygen & $\begin{array}{l}1839 \\
(64.5 \%)\end{array}$ & $\begin{array}{l}1407 \\
(64.7 \%)\end{array}$ & $\begin{array}{l}432 \\
(64.0 \%)\end{array}$ & 0.79 & 2851 & $\begin{array}{l}804 \\
(66.7 \%)\end{array}$ & $\begin{array}{l}407 \\
(67.5 \%)\end{array}$ & $\begin{array}{l}397 \\
(65.8 \%)\end{array}$ & 0.58 & 1206 \\
\hline $\begin{array}{l}\text { High flow oxygen } \\
\text { delivery }\end{array}$ & $\begin{array}{l}436 \\
(15.3 \%)\end{array}$ & $\begin{array}{l}313 \\
(14.4 \%)\end{array}$ & $\begin{array}{l}123 \\
(18.2 \%)\end{array}$ & 0.018 & 2851 & $\begin{array}{l}210 \\
(17.4 \%)\end{array}$ & $\begin{array}{l}102 \\
(16.9 \%)\end{array}$ & $\begin{array}{l}108 \\
(17.9 \%)\end{array}$ & 0.70 & 1206 \\
\hline $\begin{array}{l}\text { High flow nasal } \\
\text { canula }\end{array}$ & $\begin{array}{l}153 \\
(5.37 \%)\end{array}$ & $\begin{array}{l}120 \\
(5.51 \%)\end{array}$ & $\begin{array}{l}33 \\
(4.89 \%)\end{array}$ & 0.59 & 2851 & $\begin{array}{l}69 \\
(5.72 \%)\end{array}$ & $\begin{array}{l}42 \\
(6.97 \%)\end{array}$ & $\begin{array}{l}27 \\
(4.48 \%)\end{array}$ & 0.08 & 1206 \\
\hline $\begin{array}{l}\text { Non-invasive } \\
\text { ventilation }\end{array}$ & $\begin{array}{l}79 \\
(2.77 \%)\end{array}$ & $\begin{array}{l}55 \\
(2.53 \%)\end{array}$ & $\begin{array}{l}24 \\
(3.56 \%)\end{array}$ & 0.20 & 2851 & $\begin{array}{l}35 \\
(2.90 \%)\end{array}$ & $\begin{array}{l}17 \\
(2.82 \%)\end{array}$ & $\begin{array}{l}18 \\
(2.99 \%)\end{array}$ & 1.00 & 1206 \\
\hline $\begin{array}{l}\text { Invasive } \\
\text { mechanical } \\
\text { ventilation }\end{array}$ & $\begin{array}{l}367 \\
(12.9 \%)\end{array}$ & $\begin{array}{l}253 \\
(11.6 \%)\end{array}$ & $\begin{array}{l}114 \\
(16.9 \%)\end{array}$ & $<0.001$ & 2851 & $\begin{array}{l}169 \\
(14.0 \%)\end{array}$ & $\begin{array}{l}74 \\
(12.3 \%)\end{array}$ & $\begin{array}{l}95 \\
(15.8 \%)\end{array}$ & 0.10 & 1206 \\
\hline \multicolumn{11}{|l|}{ Outcomes } \\
\hline Hospital stay, days & $\begin{array}{l}8.00 \\
{[5.00 ; 12.0]}\end{array}$ & $\begin{array}{l}8.00 \\
{[4.00 ; 11.0]}\end{array}$ & $\begin{array}{l}8.00 \\
{[5.00 ; 13.0]}\end{array}$ & 0.001 & 1969 & $\begin{array}{l}8.00 \\
{[5.00 ; 13.0]}\end{array}$ & $\begin{array}{l}8.00 \\
{[5.00 ; 13.0]}\end{array}$ & $\begin{array}{l}8.00 \\
{[5.00 ; 13.0]}\end{array}$ & 0.47 & 745 \\
\hline Primary outcome & $\begin{array}{l}830 \\
(29.1 \%)\end{array}$ & $\begin{array}{l}584 \\
(26.8 \%)\end{array}$ & $\begin{array}{l}246 \\
(36.4 \%)\end{array}$ & $<0.001$ & 2851 & $\begin{array}{l}406 \\
(33.7 \%)\end{array}$ & $\begin{array}{l}192 \\
(31.8 \%)\end{array}$ & $\begin{array}{l}214 \\
(35.5 \%)\end{array}$ & 0.20 & 1206 \\
\hline All death & $\begin{array}{l}357 \\
(12.5 \%)\end{array}$ & $\begin{array}{l}236 \\
(10.8 \%)\end{array}$ & $\begin{array}{l}121 \\
(17.9 \%)\end{array}$ & $<0.001$ & 2851 & $\begin{array}{l}202 \\
(16.7 \%)\end{array}$ & $\begin{array}{l}91 \\
(15.1 \%)\end{array}$ & $\begin{array}{l}111 \\
(18.4 \%)\end{array}$ & 0.14 & 1206 \\
\hline Transfer to ICU & $\begin{array}{l}547 \\
(19.2 \%)\end{array}$ & $\begin{array}{l}392 \\
(18.0 \%)\end{array}$ & $\begin{array}{l}155 \\
(23.0 \%)\end{array}$ & 0.005 & 2851 & $\begin{array}{l}244 \\
(20.2 \%)\end{array}$ & $\begin{array}{l}118 \\
(19.6 \%)\end{array}$ & $\begin{array}{l}126 \\
(20.9 \%)\end{array}$ & 0.62 & 1206 \\
\hline Death in ICU & $74(2.6 \%)$ & $44(2.0 \%)$ & $30(4.4 \%)$ & 0.001 & 2851 & $40(3.3 \%)$ & $17(2.8 \%)$ & $23(3.8 \%)$ & 0.42 & 1206 \\
\hline $\begin{array}{l}\text { Death without } \\
\text { transfer to ICU }\end{array}$ & $\begin{array}{l}283 \\
(9.93 \%)\end{array}$ & $\begin{array}{l}192 \\
(8.82 \%)\end{array}$ & $\begin{array}{l}91 \\
(13.5 \%)\end{array}$ & 0.001 & 2851 & $\begin{array}{l}162 \\
(13.4 \%)\end{array}$ & $\begin{array}{l}74 \\
(12.3 \%)\end{array}$ & $\begin{array}{l}88 \\
(14.6 \%)\end{array}$ & 0.27 & 1206 \\
\hline
\end{tabular}

Data are presented as numbers (\%) and mean \pm SD, or median (25th; 75th percentile) if not normally distributed.

Table 3: Hazard ratio for outcomes during follow-up in patients with versus those without diabetes in the PSM cohort 


\begin{tabular}{|lll|}
\hline & Hazard Ratio $(95 \% \mathrm{CI})$ & $\boldsymbol{P}$ \\
\hline Primary outcome & $1.16(0.95-1.41)$ & 0.14 \\
\hline In-hospital mortality & $1.29(0.97-1.69)$ & 0.08 \\
\hline Mortality in ICU & $1.42(0.75-2.70)$ & 0.28 \\
\hline Mortality without transfer to ICU & $1.26(0.93-1.72)$ & 0.14 \\
\hline Transfer to ICU* & $1.14(0.88-1.47)$ & 0.31 \\
\hline
\end{tabular}

* Patients with a decision to Withdraw life-sustaining therapy were exclude from the analysis

$\mathrm{Cl}$, confidence interval.

\section{Figures}

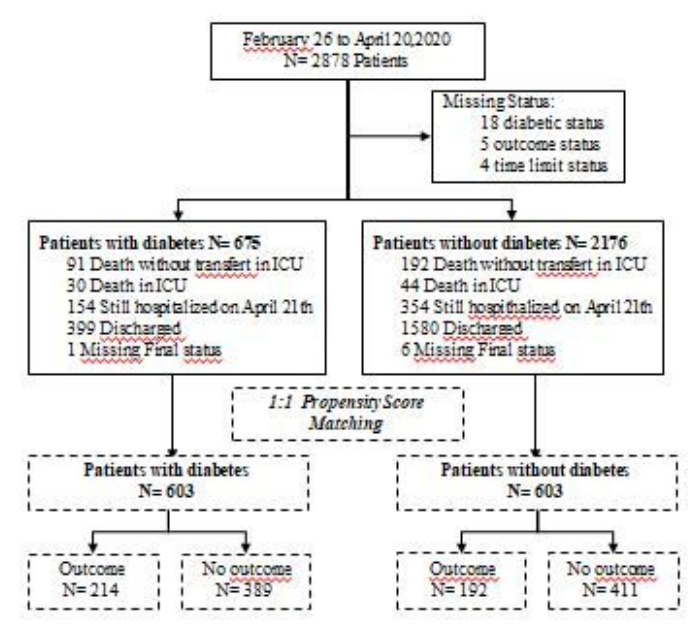

\section{Figure 1}

Flow Chart. ICU: intensive care unit 

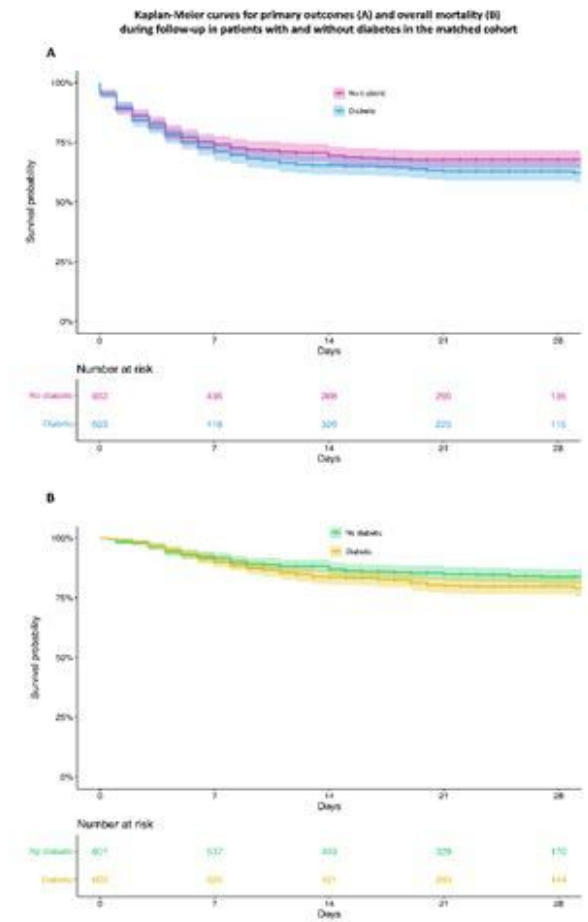

Figure 2

Kaplan-Meier curves for primary outcome (A) and overall mortality (B) during follow-up in patients with and without diabetes in the PSM cohort

\section{Supplementary Files}

This is a list of supplementary files associated with this preprint. Click to download.

- SuppldataSFCcoviddiab16july20.docx 